\title{
Indicators to Measure a Smart Building: An Indonesian Perspective
}

\author{
Indrawati, Rosiana Yuliastri, and Husni Amani
}

\begin{abstract}
Facing the big number of urban population, the city should implement smart city concept that can help urban citizen to improve their quality of life. A component of a smart city is smart building. Implementing smart building concept especially in Indonesia is important due to the urbanization rate is over the average of urbanisation in South Eastern Asia and Asia. This paper is a working paper discuss the dimensions and indicators of a smart building coming from existing literatures, ideas from 23 respondents who are business players, experts, and customers' of smart building in Indonesia. This study finds that there are seventh dimensions and 22 indicators to measure if a building has implemented a smart building concept.
\end{abstract}

Index Terms - Smart city, smart building, urban, quality of life, and Indonesia.

\section{INTRODUCTION}

The population of the world is predicted to reach 9 billion with the urban population to grow between 2.5 billion to 3 billion people in the next 30 years. A growing global population will increase energy demand by $56 \%$ in 2040 [1]. Therefore, we have to find a way to improve the residents' quality of life, manage available resources such as energy, water, transportation, and electricity in economically sustainable manner, and reduce environmental pollution. The city should be managed in such a way that can help urban citizen to sustain themselves. Designing, implementing, and measuring the smart city readiness is very important. The planning, designing, implementing, and measuring the smart city concept is very important since it can impact positively on several aspects of city life such as how and where people live, fulfill their needs, wants, and demands as well as how people support their lifelong needs in a city.

There are several 98 cities in Indonesia, some of the cities has already declared to start as a smart city, such as Bandung, Jakarta, and Surabaya. Bandung is considered as a smart city by Smart City Expo World Congress, it had been nominated as the finalist world smart city award 2015 along with six other cities all over the world. The concept of Bandung as a smart city has already been launched by Ridwan Kamil, mayor of Bandung. Bandung has already made efforts to become a smart city. These efforts have

Manuscript received October 9, 2017; revised December 13, 2017.

Indrawati, Rosiana Yuliastri, and Husni Amani are with the Faculty of Economics and Business, Telkom University, Indonesia (e-mail: Indrawati@telkomuniversity.ac.id, osiyuli@gmail.com, husni@telkomuniversity.ac.id). utilized a significant amount of money and energy. The efforts should be measured in order to improve it for a better result to achieve better city life.

There are a lot of definitions and concepts of a smart city. A smart city concept from Frost and Sullivan [2] stated that a smart city is a city that is build on "Smart" and "Intelligent" solutions and technology. The smart and intelligent solutions and technology will lead to the adoption of at least 5 of the 8 smart parameters, namely: smart energy, smart building, smart mobility, smart healthcare, smart infrastructure, smart technology, smart governance and smart education, smart citizen.

This paper is a working paper discussed the indicators of a smart building coming from existing literatures, ideas from business players, experts, and customers' of smart building in Indonesia. The short term objective is to find out the indicators and the long term objective is to help the building developers in creating smart building which will be adopted by citizen in smart cities in Indonesia as well as other cities in the world. The idea of choosing smart building is the fact that Indonesia has finished 9 skyscrapers with the total highest 1,908 meter in 2015. Indonesia became the second country after China which succeeds in finishing high buildings. In the near future, there are a lot of new high building projects in big cities in Indonesia, such as in Surabaya, Bandung, Semarang, Bogor and Makassar. The existences of new buildings are needed to accommodate the demand from the citizens. The numbers of population in cities are highly growth, due to the birth rate and urbanization. Especially in Indonesia, the urbanization is the $58 \%$ in 2016 and it is over the average of urbanisation in South Eastern Asia and Asia. The population in urban is growing sharply while the population in rural areas decrease [3].

The existences of buildings are important in city life, as written in a Harvard Business Review [4] article that smarter building is the foundation for smart cities, but the existence of each building has a contribution to the total building annual energy consumption which is $40 \%$ of total energy consumption [5]. In Indonesia energy consumption index reaches $250,000 \mathrm{kwh} / \mathrm{m}$-sq/year [6]. If there is no effort to save the energy, in the near future the availability of energy will become a big problem. The existences of buildings not only affect the energy consumtion but also affect the gas emitters which reach $21 \%$ gas emission. Accenture Consultant [7] stated that commercial buildings are also expensive. After salaries, buildings are one of the biggest operational expenditures for organizations'. 


\section{Research OBJeCtives AND QuESTIONS}

The negative effects of buildings existences should be eliminated wisely; the buildings should be built and managed in a smart way. The buildings developed should be smart buildings. In order to be able to build smart buildings, it is important to identify the indicators of smart buildings. As far as this study doing literature reviews, this study cannot find any convincing indicators to be used for measuring a smart building directly, especially the one fit with Indonesian characteristics. Citizen's characteristics, social and economic back ground of Indonesia have quite different from other countries. A model or indicators which can be implemented in a country might not be able to be directly implemented well in other countries [8]. Therefore, the objectives of this study are to find out the dimensions, indicators, and items which fit to be used for measuring smart building in Indonesia. In line with the objectives the research questions that want to be answered are: a) Based on the literature result, what are the dimensions and indicators to measure a smart building in Indonesia? b) Based on interview and FGD result, what are the dimensions and indicators to measure a smart building in Indonesia? and c) What items that can be used to measure a smart building in Indonesia?

\section{ReSEARCH Methodology}

In order to achieved the research objectives and answer the research questions, this study applies two steps in identifying the indicators of smart buildings, first step is literature review and second step is focus group discussion (FGD) and depth interview. In doing the first step, literature review, this study use primary literature such as articles from journals and conferences proceedings which are available on line in the internet and modern electronic search engines, as well as electronic data bases available in Telkom University campus and other facilities connected to Telkom University campus as suggested by Zikmund, Babin, Carr, and Griffin [9], Indrawati [10]. Besides primary literature, this study also uses secondary literature such as books, review articles, indexes and abstracts, and also uses tertiary literature, such as encyclopaedias and dictionaries.

The process of literature review was done by reading all related literatures with the object of this study, compare one literature to others to find out the similarities, contrast one literature to others to find out the differences, criticize the literature to give view and synthesize the literature to compare one to others andfinally summarize what the literatures say about indicators of smart buildings.

The second step which is done in this study is FGD and interview. FGD was done following the idea of Zikmund, Babin, Carr, and Griffin [9] who stated that FGD are a very important qualitative research technique and deserve considerable discussion. Through FGD, people are more willing to talk about things when they are able to do so within a group discussion format rather than individual interview. By applying FGD, respondents could feed on each other's comments to develop ideas which might be difficult to express in a different interview format. Therefore, by applying this FGD format, it is hoped that the ideas are more developed and comprehensive. When the targeted respondents are not available for FGD, this study used individual depth interview. Zikmund, Babin, Carr, and Griffin [9] stated that depth interview is an alternative to an FGD. It is a one-on-one interview between a professional researcher and a research respondent.

The steps of FGD is done through 3 steps following the one already done by World Health Organization-WH0 [11], first deciding participants of FDG by finding the ultimate people from governments, experts, practitioners, and customers or prospective customers of smart building. Each group is separated in different FGD. Second is to decide and explain the objectives of the current FGD, namely to find out dimensions and indicators of a smart building in Indonesia. Third is the suggestions or ideas of a smart building from the FGD are transcribed and grouped into dimensions and indicators. Based on the dimensions and indicators found, a checklist to measure a smart building was developed.

The checklist is a faithful summary of the views expressed by the focus group participants. The checklist is intended to provide a universal standard for a smart building.

In doing depths interviews, the researchers ask many questions and follow up each answer with probes for additional elaboration. An open ended interview format used to ensure that the information obtained would be related to the objectives on the study. Open-ended questions were prepared and were given to the respondents. The interviewers adusted the sequence of the questions given and added questions based on the responses of the respondents, during the interview the researchers recorded the interview and transcribe edit after the interview finished [12].

To enhance confidence of the information, this study applied both data and investigator triangulation, the data triangulation is done through involving different sources of information and investigator triangulation is done through involving more than one data collectors [10]. During the interview, this study applied at least two interviewers who make research notes and put the codes on every meaningful statement of interviewees. The interviewers check the interpretation against the interviewees and peer interviewer to reduce bias of a single interviewer and for confirmation of the collected textual data.

The respondents for both FGD and depth interview were selected from 4 different positions, namely from government, business players, experts, and customers which are chosen by using purposive sampling technique a long with snowball sampling. In purposive sampling technique the sample is selected when the sampling is confined to specific types of people who can provide the desired information, either because they are the only ones who have it or because they conform to some criteria set by the researcher [13]. Snowball sampling allows the researcher to generate a larger sample by asking participants to identify their colleagues. Table I shows the respondents of this research. 
TABLE I: LIST OF RESPONDENTS

\begin{tabular}{|c|c|c|c|}
\hline No & Category & $\begin{array}{c}\text { Organizations or } \\
\text { Institutions of } \\
\text { Respondents } \\
\end{array}$ & Number \\
\hline \multirow{2}{*}{1} & \multirow{2}{*}{ Government } & $\begin{array}{l}\text { Bandung Government } \\
\text { Smart City Team }\end{array}$ & 2 \\
\hline & & $\begin{array}{l}\text { Jakarta Government Smart } \\
\text { City Team }\end{array}$ & 4 \\
\hline \multirow[b]{2}{*}{2} & \multirow{2}{*}{$\begin{array}{l}\text { Business } \\
\text { Players }\end{array}$} & PT. Sigma Cipta Caraka & 1 \\
\hline & & $\begin{array}{l}\text { Smart City Nusantara of } \\
\text { Telkom Indonesia }\end{array}$ & 4 \\
\hline \multirow[t]{2}{*}{3} & \multirow{2}{*}{$\begin{array}{l}\text { Users/ } \\
\text { Customers }\end{array}$} & $\begin{array}{l}\text { Owner, Management, } \\
\text { Tenant HRB }\end{array}$ & 1 \\
\hline & & Customers & 4 \\
\hline \multirow{3}{*}{4} & \multirow{3}{*}{$\begin{array}{l}\text { Researchers/ } \\
\text { Observers/ } \\
\text { Experts }\end{array}$} & $\begin{array}{l}\text { Lecturers of Telkom } \\
\text { University }\end{array}$ & 2 \\
\hline & & $\begin{array}{l}\text { Smart city research group of } \\
\text { Bandung Institute of } \\
\text { technology }\end{array}$ & 4 \\
\hline & & $\begin{array}{l}\text { Researcher of Digital } \\
\text { Service Division of Telkom } \\
\text { Indonesia }\end{array}$ & 1 \\
\hline \multicolumn{3}{|r|}{ Tot a 1} & 23 \\
\hline
\end{tabular}

The collected textual data were processed and analysed following the six steps of analysing textual data from Cresswell [12], namely organizing and prepare the data for analysis, read through all the data, detailed analysis with textual data coding process and segments the text, use the coding process to generate a description of the setting or people as well as categories or themes for analysis, advance how the descriptive and themes are represented in the qualitative narrative and in this research are also in descriptive percentage, and the last step is making interpretation of the data. In this process also include comparison the meaning of findings from analysing textual data with the information derived from literature or theories reviewed. Through this step this study could conclude that the findings confirm the past information or diverge, and since these qualitative researchers use a theoretical lens, the researchers can form interpretations that call for action agendas for reform or develop a model or achieve innovation of conceptual frameworks [14].

\section{SMART BuILDING CRITERIA: Literature REVIEW RESULT}

The literature review that has been done started with finding of the definitions of smart building and followed by exploring the dimension as well as the indicators of smart building.

\section{A. Smart Building Definition}

There are various definitions of smart building depends upon the point of view of people who define it. The following is a definition of smart building of Al-Habaibeh as written by Hume [5] that "A smart building is a building with changeable characteristics that can respond withminimum human interference to change in the external and internal environments forthe benefit and comfort of the occupant, taking into consideration the financialperspective and reduction in energy use". Al Habaibeh also stated that a smart building is the ones that can look after themselves against changing parameters rather than set parameters.
The second definition of smart building comes from Tony Sung as cited by Hume [5] that "A smart building should have the ability to integrate automated building controlsand optimise operations to lowering both cost and energy usage compared to theconventional buildings".

Third definition come from Buckman, Mayfield, Beck, Stephen [15], they stated that a smart building is a building which integrates and accounts for intelligence, enterprise, control, and materials as well as construction as an entire building system. A smart building should be able to be adaptive not reactivate, at the core, in order to meet the drivers for energy and efficiency, longevity, and comfort as well as satisfaction.

Smart Building is also defined as "a collaboration of Telecommunications, Building Automation, System Integration and Office Automation for optimizing economic, efficiency, conformability, functionality, and stability of Intelligent Building. It is pursuing energy efficiency and green building for nature friendly environment" [16].

Based on the four definitions of a smart building above, a smart building should be able to control itself with minimum human interference therefore it should be integrated with automated building control to optimise operation to lowering both cost and energy usage.

\section{B. Smart Building Dimensions and Indicators}

Based on the eight literatures related to a smart building, this study makes a table to summarize the smart building dimensions as shown in Table II.

TABLE II: SMART BUILDING DIMENSION FROM LITERATURES

\begin{tabular}{|c|c|c|c|c|c|c|c|c|}
\hline Dimensions $\backslash$ sources & 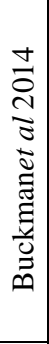 & 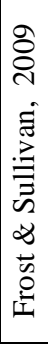 & 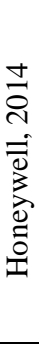 & 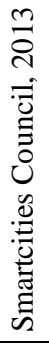 & 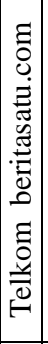 & 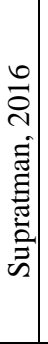 & 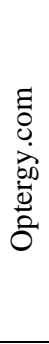 & 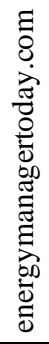 \\
\hline $\begin{array}{l}\text { Building Automation } \\
\text { System }\end{array}$ & $\sqrt{ }$ & $\sqrt{ }$ & $\sqrt{ }$ & $\sqrt{ }$ & $\sqrt{ }$ & $\sqrt{ }$ & $\sqrt{ }$ & $\sqrt{ }$ \\
\hline Building Control System & $\sqrt{ }$ & & $\sqrt{ }$ & $\sqrt{ }$ & & $\sqrt{ }$ & $\sqrt{ }$ & $\sqrt{ }$ \\
\hline $\begin{array}{l}\text { Energy Management } \\
\text { System }\end{array}$ & & $\sqrt{ }$ & $\sqrt{ }$ & & $\sqrt{ }$ & $\sqrt{ }$ & $\sqrt{ }$ & $\sqrt{ }$ \\
\hline $\begin{array}{l}\text { Security Management } \\
\text { System }\end{array}$ & $\sqrt{ }$ & & $\sqrt{ }$ & $\sqrt{ }$ & & & $\sqrt{ }$ & $\sqrt{ }$ \\
\hline $\begin{array}{l}\text { Enterprise Management } \\
\text { System }\end{array}$ & $\sqrt{ }$ & & & $\sqrt{ }$ & & $\sqrt{ }$ & & \\
\hline IT Network Connectivity & $\sqrt{ }$ & & $\sqrt{ }$ & $\sqrt{ }$ & $\sqrt{ }$ & $\sqrt{ }$ & $\sqrt{ }$ & \\
\hline $\begin{array}{l}\text { Green Building } \\
\text { Constructions }\end{array}$ & $\sqrt{ }$ & & & & $\sqrt{ }$ & & & \\
\hline
\end{tabular}

Table II shows that according to Buckman et al [15], the dimension of a smart building is adaptability, control, enterprise, materials and construction. The second literature comes from Smart Cities Council [17] which stated that a smart building should have 7 dimensions, namely: Instrument and Control, connectivity, interoperability, security and privacy, data management, computing resources, and analytics. The third literature comes from Honeywell [18] who wrote that the dimensions of smart building are green, safe, comfortable and productive. The fourth literature came from Supratman [19] who wrote that the dimensions of smart buildings are building energy 
management, atomization by using information communication technology (ICT), and green building construction. The fifth literature came from Hardcastle of IBM [20] which indicates 10 dimensions namely: energy, lighting, fire, 24/7 monitoring, PEHV charging, water, HVAC, elevators, access and security. The sixth literature came from Optergy which stated that there are 5 dimensions of a smart building, namely: building control, energy management, security management, wire/wireless network, and smart lighting. The seventh literature came from Telkom which stated that a smart building as a ICT solution to integrate the functions of access control, internet connection, TV cable, CCTV, alarm, sound, digital signage, and video guard in centralized integrated system.

Based on those seventh literatures, the indicators of each dimension of a smart building are shown in Table III.

TABLE III: SMART BUILDING CRITERIA: BASED ON LITERATURE

\begin{tabular}{|c|c|c|}
\hline Dimension & Indicators & Objectives \\
\hline $\begin{array}{l}\text { Building } \\
\text { Automation } \\
\text { System }\end{array}$ & $\begin{array}{l}\text { Sensors } \\
\text { implementation to } \\
\text { manage light level, } \\
\text { air quality, } \\
\text { temperature, fire } \\
\text { alarm and smoke } \\
\text { detector. }\end{array}$ & $\begin{array}{l}\text { Improved occupant } \\
\text { comfort, efficient } \\
\text { operation of } \\
\text { building systems, } \\
\text { reduction in energy } \\
\text { consumption and } \\
\text { operating costs, and } \\
\text { improve life cycle } \\
\text { of utilities. }\end{array}$ \\
\hline \multirow[t]{3}{*}{$\begin{array}{l}\text { Building } \\
\text { Control } \\
\text { System }\end{array}$} & $\begin{array}{l}\text { Remote } \\
\text { implementation } \\
\text { monitor building } \\
\text { condition and } \\
\text { occupancy. }\end{array}$ & \multirow{3}{*}{$\begin{array}{l}\text { Understand the } \\
\text { situation and } \\
\text { performance of } \\
\text { existing systems in } \\
\text { order to improve } \\
\text { energy, operation an } \\
\text { maintanenance cost } \\
\text { saving. }\end{array}$} \\
\hline & $\begin{array}{l}\text { Realtime } \\
\text { monitoring }\end{array}$ & \\
\hline & $\begin{array}{l}\text { Implementation of } \\
\text { any software that } \\
\text { can talk to legacy } \\
\text { equipment from } \\
\text { many different } \\
\text { manufacture. }\end{array}$ & \\
\hline \multirow[t]{2}{*}{$\begin{array}{l}\text { Energy } \\
\text { Management } \\
\text { System }\end{array}$} & $\begin{array}{l}\text { Implementation of } \\
\text { power } \\
\text { consumption } \\
\text { monitoring and } \\
\text { control. }\end{array}$ & \multirow[t]{2}{*}{$\begin{array}{l}\text { Energy efficiency, } \\
\text { resource } \\
\text { conservation, } \\
\text { climate protection } \\
\text { and cost savings. }\end{array}$} \\
\hline & $\begin{array}{l}\text { Implementation of } \\
\text { energy efficient } \\
\text { electrical } \\
\text { appliance. }\end{array}$ & \\
\hline \multirow[t]{5}{*}{$\begin{array}{l}\text { Safety \& } \\
\text { Security } \\
\text { Management } \\
\text { System }\end{array}$} & $\begin{array}{l}\text { Implementation of } \\
\text { detection and } \\
\text { response to threats. }\end{array}$ & \multirow[t]{5}{*}{$\begin{array}{l}\text { Provide safety and } \\
\text { security for person, } \\
\text { asset, privacy and } \\
\text { information. }\end{array}$} \\
\hline & $\begin{array}{l}\text { Implementation of } \\
\text { controlling access } \\
\text { to the facility. }\end{array}$ & \\
\hline & $\begin{array}{l}\text { Implementation of } \\
\text { securing lives and } \\
\text { assets. }\end{array}$ & \\
\hline & $\begin{array}{l}\text { Implementation of } \\
\text { security framework } \\
\text { and cyber security. }\end{array}$ & \\
\hline & $\begin{array}{l}\text { Publish safety and } \\
\text { privacy policy. }\end{array}$ & \\
\hline
\end{tabular}

\begin{tabular}{|c|c|c|}
\hline Dimension & Indicators & Objectives \\
\hline \multirow{2}{*}{$\begin{array}{l}\text { Enterprise } \\
\text { Management } \\
\text { System }\end{array}$} & $\begin{array}{l}\text { Data management } \\
\text { framework }\end{array}$ & \multirow{2}{*}{$\begin{array}{l}\text { Provide efficiency } \\
\text { and effectiveness for } \\
\text { strategy decision } \\
\text { making }\end{array}$} \\
\hline & $\begin{array}{l}\text { System } \\
\text { information } \\
\text { management }\end{array}$ & \\
\hline \multirow[t]{2}{*}{$\begin{array}{l}\text { IT Network } \\
\text { Connectivity }\end{array}$} & $\begin{array}{l}\text { Wired / wireless } \\
\text { communication }\end{array}$ & \multirow{2}{*}{$\begin{array}{l}\text { Make all operation } \\
\text { work properly and } \\
\text { efficient. }\end{array}$} \\
\hline & $\begin{array}{l}\text { All devices } \\
\text { connected with } \\
\text { multi service } \\
\text { communication }\end{array}$ & \\
\hline \multirow{4}{*}{$\begin{array}{l}\text { Green } \\
\text { Building } \\
\text { Constructions }\end{array}$} & $\begin{array}{l}\text { Green building } \\
\text { architecture }\end{array}$ & \multirow[t]{4}{*}{$\begin{array}{l}\text { Build a green } \\
\text { building }\end{array}$} \\
\hline & $\begin{array}{l}\text { Low environment } \\
\text { impact }\end{array}$ & \\
\hline & $\begin{array}{l}\text { Resource } \\
\text { efficiency }\end{array}$ & \\
\hline & $\begin{array}{l}\text { Healthy } \\
\text { environment }\end{array}$ & \\
\hline
\end{tabular}

\section{SMART BuILding CRITERIA: BASED ON INTERVIEW \& FGD RESULT}

In order to make the dimensions and indicators of a smart building fit with Indonesia's situation, this study finds out the dimensions and indicators from Indonesia's government, business players, experts, and customers. Based on the result of interview and FGD with 23 respondents, this study found that the dimensions of a smart building are as shown in Table IV.

TABLE IV: SMART BUILDING DIMENSIONS BASED ON INTERVIEW AND

\begin{tabular}{|l|c|}
\multicolumn{1}{|c}{ Dimensions } & $\begin{array}{c}\text { \% of } \\
\text { Respondents } \\
\text { Agree }\end{array}$ \\
\hline Building Automation System & 0,94 \\
\hline Building Control System & 0,94 \\
\hline Energy Management System & 0,94 \\
\hline $\begin{array}{l}\text { Safety \& Security Management } \\
\text { System }\end{array}$ & 0,94 \\
\hline IT Network Connectivity & 0,89 \\
\hline Green Building Constructions & 0,89 \\
\hline Enterprise Management System & 0,72 \\
\hline
\end{tabular}

Table IV shows that $94 \%$ of respondents agree that Building Automation System, Building Control System, Energy Management System, and Safety \& Security Management system as dimension of a smart building. $89 \%$ of respondents agree that IT Network Connectivity and Green Building Construction as dimension of a smart buiding, and $72 \%$ of respondents agree that Enterprise Management System as one of dimension of a smart building.

Based on the result of interview and FGD with 23 respondents, this study found that the indicators of a smart building are as shown in Table $\mathrm{V}$. 
TABLE V: SMART BUILDING INDICATORS BASED ON INTERVIEW AND FGD

\begin{tabular}{|c|c|c|}
\hline Dimensions & Indicators & $\begin{array}{c}\% \text { of } \\
\text { Respondents } \\
\text { Agree }\end{array}$ \\
\hline $\begin{array}{l}\text { Building } \\
\text { Automation } \\
\text { System }\end{array}$ & $\begin{array}{l}\text { a. Sensors } \\
\text { implementation }\end{array}$ & 0,94 \\
\hline \multirow[t]{3}{*}{$\begin{array}{l}\text { Building } \\
\text { Control } \\
\text { System }\end{array}$} & $\begin{array}{l}\text { a. Remote implementation } \\
\text { monitor building } \\
\text { condition and } \\
\text { occupancy }\end{array}$ & 0,78 \\
\hline & b. Realtime monitoring & 0,83 \\
\hline & $\begin{array}{l}\text { c. Implementation of any } \\
\text { software that can talk to } \\
\text { legacy equipment from } \\
\text { many different } \\
\text { manufacture }\end{array}$ & 0,83 \\
\hline \multirow[t]{3}{*}{$\begin{array}{l}\text { Energy } \\
\text { Management } \\
\text { System }\end{array}$} & $\begin{array}{l}\text { a. Implementation of } \\
\text { power consumption } \\
\text { monitoring and control. }\end{array}$ & 0,83 \\
\hline & $\begin{array}{l}\text { b. Implementation of } \\
\text { energy efficient } \\
\text { electrical appliance. }\end{array}$ & 0,83 \\
\hline & $\begin{array}{l}\text { c.Implementasi of backup } \\
\text { enerrgi }\end{array}$ & 0,67 \\
\hline \multirow{5}{*}{$\begin{array}{l}\text { Safety \& } \\
\text { Security } \\
\text { Management } \\
\text { System }\end{array}$} & $\begin{array}{l}\text { a. Implementation of } \\
\text { detection and response } \\
\text { to threats. }\end{array}$ & 0,83 \\
\hline & $\begin{array}{l}\text { b. Implementation of } \\
\text { controlling access to the } \\
\text { facility. }\end{array}$ & 0,83 \\
\hline & $\begin{array}{l}\text { c. Implementation of } \\
\text { securing lives and } \\
\text { assets. }\end{array}$ & 0,78 \\
\hline & $\begin{array}{l}\text { d. Implementation of } \\
\text { security framework and } \\
\text { cyber security. }\end{array}$ & 0,89 \\
\hline & $\begin{array}{l}\text { e. Publish safety and } \\
\text { privacy policy. }\end{array}$ & 0,78 \\
\hline \multirow{3}{*}{$\begin{array}{l}\text { Enterprise } \\
\text { Management } \\
\text { System }\end{array}$} & $\begin{array}{l}\text { a. Data management } \\
\text { framework }\end{array}$ & 0,83 \\
\hline & $\begin{array}{l}\text { b. System information } \\
\text { management }\end{array}$ & 0,83 \\
\hline & c. Data analytic & 0,72 \\
\hline \multirow[t]{3}{*}{$\begin{array}{l}\text { IT Network } \\
\text { Connectivity }\end{array}$} & $\begin{array}{l}\text { a. Wired / wireless } \\
\text { communication }\end{array}$ & 0,83 \\
\hline & $\begin{array}{l}\text { b. All devices connected } \\
\text { with multi service } \\
\text { communication }\end{array}$ & 0,78 \\
\hline & $\begin{array}{l}\text { c. Availability dan } \\
\text { realibility network }\end{array}$ & 0,83 \\
\hline \multirow{4}{*}{$\begin{array}{l}\text { Green } \\
\text { Building } \\
\text { Constructions }\end{array}$} & $\begin{array}{l}\text { a. Green building } \\
\text { architecture }\end{array}$ & 0,67 \\
\hline & $\begin{array}{l}\text { b. Low environment } \\
\text { impact }\end{array}$ & 0,72 \\
\hline & c. Resource efficiency & 0,72 \\
\hline & d. Healthy environment & 0,72 \\
\hline
\end{tabular}

Fig. 1. Proposed Model to measure a smart building in Indonesia.

\section{CONCLUSION}

Referring to the literature review results and interview and FGD result, this study find that both of results suggests the same seventh dimension, but in term of indicators the findings is a bit different since based on interview and FDG result the indicator of Backup Energy Implementation should be added to Energy Management System dimension, Data Analytic indicator should be added to Enterprise Management System dimension, and Availability and Reliability Network indicator should be added to IT Network Connectivity dimension. Therefore, model for measuring smart building in Indonesia is presented in Fig. 1.

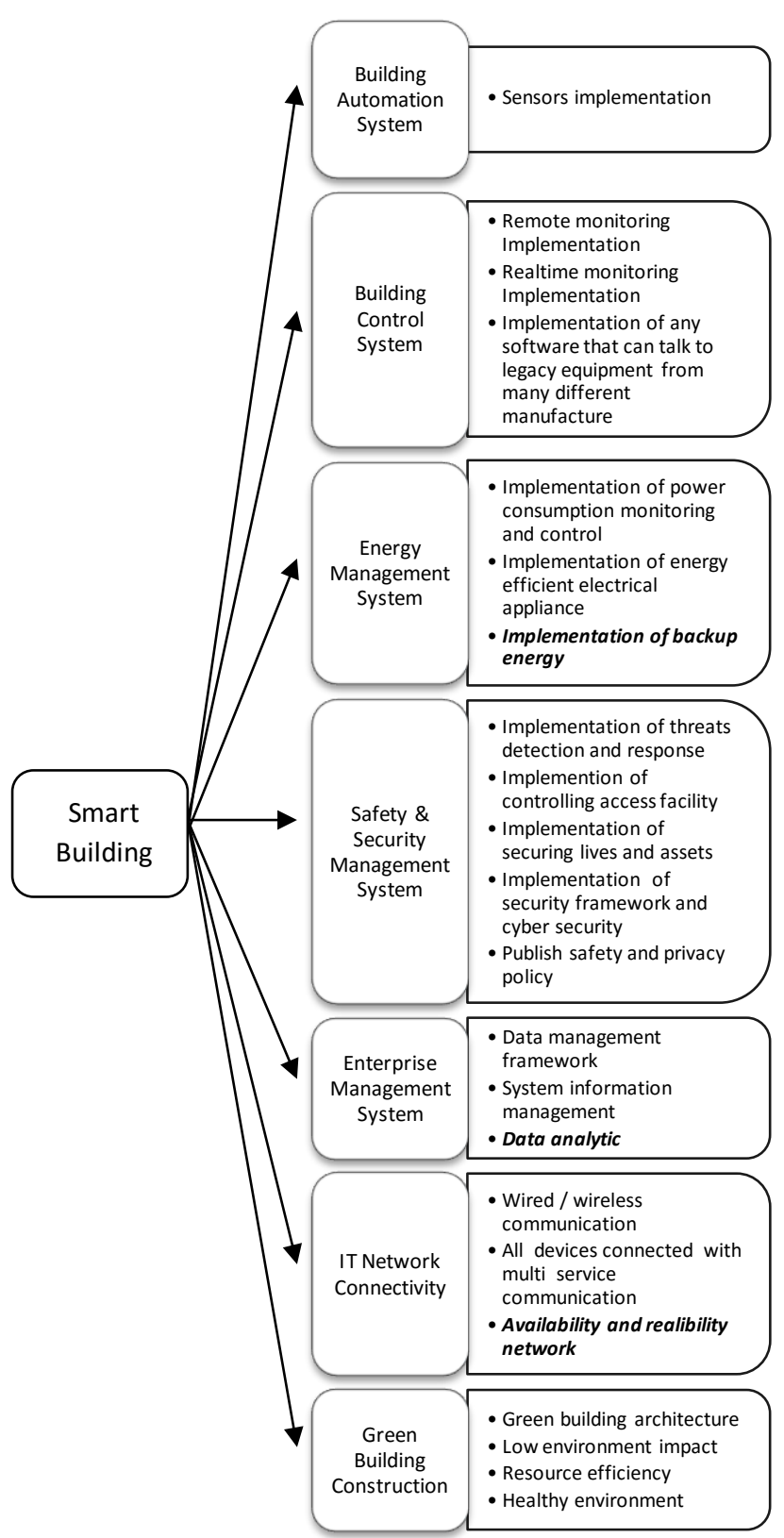

Fig. 1. Proposed model to measure a smart building in Indonesia.

The next process that will be done by the writers are composing the measurement tool, in this case is a set of questionnaire, and test it through pilot test. Once the measurement tool is valid and reliable, it will be used to collect main data to test if the proposed model can be applied to measure smart buildings in Indonesia.

\section{ACKNOWLEDEMENT}

The authors of this research would like to express their gratitude to Ministry of Research, Technology and Higher Education of Indonesia for supporting their financial in doing this research. 


\section{REFERENCES}

[1] Daniel Gutierrez. (October 25, 2015). The benefit of becoming a smart city. Inside Bigdata. [Online]. Available: http://insidebigdata.com/2015/10/25/the-benefits-of-becoming-asmart-city/

[2] Frost \& Sullivan, Strategic Opportunity Analysis of the Global Smart City Market, Maxim Perevesentsev: Kazakhstan, Tidak diterbitkan, 2009.

[3] UN. Country profiles. [Online]. Available: https://esa.un.org/unpd/wup/Country-Profiles/

[4] Smart cities start with smart buildings. (2016). Harvard Business Review. [Online]. Available: https://hbr.org/sponsored/2016/01/smart-cities-start-with-smartbuildings

[5] D. Hume. (2013). Irisys technology adds intelligence to smart buildings. Exploring what is mean by a smart building and how infrared detectors are being used to make building more intelligent. [Online]. http://cdn2.hubspot. net/hub/13940/file257413033pdf/docs/Smart_Buildings_White_Paper_Aug_2013.pdf

[6] Iskandar, Smart Building toward Green Building, 2016.

[7] Accenture Consultant, "Energy-Smart buildings: Demonstrating how information technology can cut energy use and costs of real estate portfolios," Accenture Consultant, 2011.

[8] Indrawati, S. Murugesan, and M. Raman, "A new conceptual model of mobile multimedia service (MMS) and $3 \mathrm{G}$ network adoption in Indonesia," International Journal of Information Science and Management (IJISM), Regional Information Center for Science and Technology, 2010.

[9] W. G. Zikmund, B. J. Babin, J. C. Carr, and M. Griffin, Business Research Methods, 8th ed. New Castle: South-Western College Pub, 2009.

[10] Indrawati, Metode Penelitian Manajemen dan Bisnis: Konvergensi Teknologi Komunikasi dan Informasi, Bandung Indonesia: Refika Aditama, 2015.

[11] WHO, Global Age-friendly Cities: A Guide, France: World Health Organization, 2007.

[12] J. W. Creswell, Research Design: Qualitative, Quantitatve, and Mixed Methods Approaches, 3rd ed. Singapore: Sage Publication Inc., 2009.

[13] U. Sekaran and R. Bougie, Research Method for Business, A Skill Building Approach, 5th ed. Singapore: John Wiley \& Sons Inc., 2010.

[14] W. Olsen, "Trianggulation in social research: Qualitative and quantitative methods can really be mixed, a chapter in developments in sociology," Ormskirk: Causeway Press, 2004.

[15] A. H. Buckman, M. Mayfield, and S. B. M. Beck, "What is smart Building?" Journal of Smart and Sustainable Built Environment, vol. 3, no. 3, pp. 92-109, 2014.

[16] Products. [Online]. Available: https://luxter.com/products
[17] Smart Cities Council, 2013.

[18] Honeywell, Put Your Buildings To Work: A Smart Approach To Better, 2014.

[19] Supratman. (2016). Smart building solution for high rise building. The smart way for green building. [Online]. Available: https://kampiun.telkom.co.id/kampiun/kampiun/main.php

[20] J. L. Hardcastle. (2013). IBM smarter building technology helps schools cut costs. [Online]. Available: http://www.energymanagertoday.com/ibm-smarter-buildingtechnology-helps-schools-cut-costs-088924/

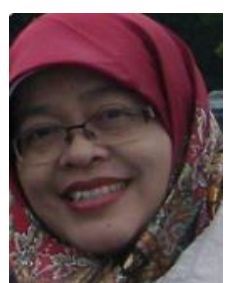

Indrawati was born in Indonesia and received her master degrees from Padjadjaran University (UNPAD), Indonesia, majoring in Management. She received her Ph.D. in Faculty of Management, Multimedia University (MMU) Malaysia. Indrawati's research interests include Adoption of Services based on technology, competitive intelligent, innovation, new product development, new product acceptance, creative industry, e-commerce, and smart city. She has published more than 300 articles in newspaper, tabloid, magazines, national (in Indonesia) and international proceedings and journals, as well as books. Several of her articles have got awards in several events, such as: the eight best articles on the 4th International Conference on E-Commerce with Focus on Developing Countries (ECDC), Kuala Lumpur Malaysia on 3-4 November, 2009, the best paper on Smart Collaborations for Business in Technology and Information Industries (SCBTII) Conference, Bandung Indonesia August 15-16, 2016, and the best paper on International Seminar and Conference on Learning Organization (ISCLO) 2016, Bandung Indonesia, October 26, 2016.

Rosiana Yuliastri was born in Indonesia and received her master degrees from Telkom University, Indonesia, majoring in economics and business Her Research interests as well as papers published include smart city areas. Currently Rosiana Yuliastri is a senior officer IT Investment Management of PT. Telekomunikasi Indonesia.

Husni Amani was born in Indonesia and received his master degrees from Prasetya Mulya Business School, Indonesia, majoring in business management and Anglia Polytechnic University UK majoring in telecommunications management. Husni received his doctor degree from the Faculty of Economy and Business UNPAD Indonesia. His research interests as well as papers published include in industrial engineering, ICT business management, investor relations, tourism as well as Smart City areas. Currently Husni Amani is a senior lecturer in the faculty of Industrial Engineering, Telkom University, Bandung Indonesia. 